\title{
Identification of pollution sources in closed mining sites with an Impact on the quality of surface water in the Brad area
}

\author{
Emilia-Cornelia Dunca ${ }^{1 *}$, Tiberiu Rusu ${ }^{2}$, and Dorin Iancu ${ }^{3}$ \\ ${ }^{1}$ University of Petrosani, Department of Environmental Engineering and Geology, University Street \\ 20, Petrosani, Romania \\ 2 Technical University of Cluj Napoca, Department of Environmental Engineering and Sustainable \\ Development Entrepreneurship, Bd. Muncii 103-105 Cod 400641 Cluj-Napoca, Romania \\ ${ }^{3}$ National Commission for the Control of Nuclear Activity, B-dul. Libertatii, Nr. 14, Sector 5, \\ Bucharest, Romania
}

\begin{abstract}
Pollution caused by closed mining activities is particularly difficult to treat because it dates back a very long time. Water contamination results from large-scale disturbance of the land on which the underground exploitation of the useful mineral substance took place. Discharges from underground mines can be treated as diffuse point sources; water quality is due to reactions that occur in an area that can cover tens of square kilometres. The main sources are groundwater, which increases after the pumping is stopped, and tailings stored in dumps and tailings ponds. When the mine closes, the pumps are stopped and the groundwater level rises until it reaches the surface or discharges into the aquifers above. Although discharges from wells and galleries are often the most visible sources, surface activities such as mineral processing, tailings and waste disposal are also a significant source of pollution. The river is located on the Barza gold-silver ore mining operation took place. The runoff waters present in this perimeter can transport contaminated sediments, where the tailings dumps are washed away by precipitation. The paper aims to identify the sources of surface water pollution in the Barza closed mining site that influences the quality of surface water.
\end{abstract}

\section{Introduction}

The environmental challenges of mining are in several areas, namely: availability, use and treatment of water; real-time water quality monitoring; acid water management; tailings management and recovery; mine closure management [1]. Through the Mining Restructuring Program, in 1996 the Romanian Government decides to close the non-viable mining operations. They were closed in accordance with the provisions of ANRM (National Agency for Mineral Resources) and the Mining Law no. 61/1998, taking into account the economic situation of the country, the socio-economic effects that are reflected on the labor force and other norms established by the decision makers in this sector.

* Corresponding author: duncaemilia@yahoo.com 
The closure of a mining operation is carried out in accordance with the Romanian Mine Closure Manual, which specifies all the indispensable operations and tools, regarding the techniques and methods of supervision and control necessary for the closure process. The mine closure manual requires actions to monitor the effectiveness of the closure plan and conservation plan, in line with international best practice. Pollution produced by closed / abandoned mining operations, manifests itself on all environmental components, but mainly on water and soil, being the most visible and widespread as a direct or indirect effect of mining in the area. It is likely that certain areas of the mining perimeter will cause major pollution, but the effect will be local, in surface waters and groundwater (Environmental management in the mining sector) $[2,3]$.

\section{Description of the Barza mining operation}

The Barza mining perimeter, which from an administrative point of view belongs to the National Company of Copper, Gold and Iron „MINVEST” S.A. Deva, is located in the Ore Mountains on the territory of Crișcior commune, Hunedoara County. In the Barza mining operation, activities were carried out for the underground extraction of gold and silver ores. The mining activity ended in 2006, and the Barza mine entered an extensive closure process. The tailings resulting from the underground mining works at the Barza mine were deposited in the Blojului Valley dump, at approx. $3 \mathrm{~km}$ away (Figure 1) [4].

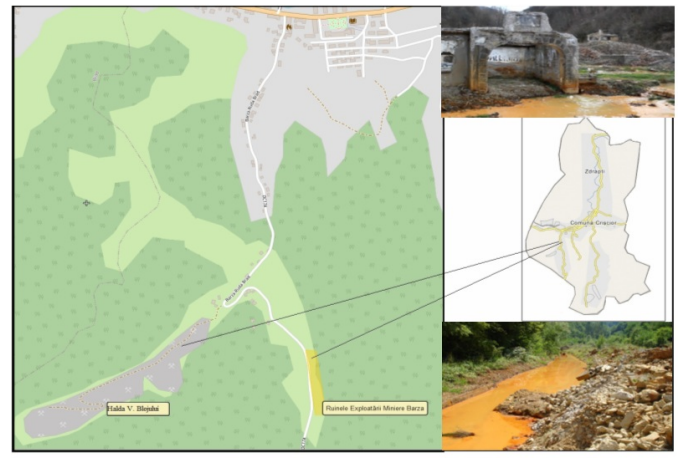

Fig. 1. Location of the Barza mine.

The Stork deposit belongs to the category of native gold deposits and gold polymetallic sulphides associated with Neogene's volcanism in the Metaliferi Mountains, Brad Săcărâmb area. From a genetic point of view, the Barza deposit is a hydrothermal type filonian. Around it and inside the volcanic bodies are known several vein groups (Musariu, Brădişor, Carpen, Cireşata, Plumb and Ruda) [4].

The hydrographical component of the environment has the polarizing role in the distribution of the human community and their related habitats. It can be said that water is the basic factor of geo-systemic integrity. The waters take over, through precipitation, the residues of the activity of exploitation and processing of ores, regardless of their state of aggregation, and store them in its composition, in solution or suspension. Thus, its qualitative parameters change, generating a real chain of negative effects throughout its circuit in nature [4].

In 2006 the Barza mine was closed. The premises of the Barza mine that served this operation were demolished, and the Barza mine mouth, the 1 Mai galleries was closed and concreted, some of the installations and the iron were cut and recovered. The water from the underground works, which are no longer pumped, comes to the surface through the closed mine mouth. These mine waters are acidic and pollute surface and groundwater over 
a large area. Between the rubble is observed the mine water that puddles on the surface of the soil. The affected environmental components of this mining perimeter are: soil, water, air and vegetation.

The underground mining in the Barza mine affects to a lesser extent the surface of the land because the exploitation methods used (the method of exploitation with backfilling of the exploited space and the method of exploitation with storage) deposit the tailings in the exploited space.

Currently, in the Barza mine area, only the rubble resulting from the demolition of the mining premises, the acid mine waters and the alluvium transported by the Barza brook affect the environment. Due to the acidic $\mathrm{pH}$ (fish die at $\mathrm{pH}=4.5$ ), these waters reached the emissary have the effect of destroying the aquatic flora and fauna, preventing the use of water for recreation, irrigation, water supply etc.

\section{Identify sources of pollution perimeter Barza}

Changes in land use before, during and after the cessation of mining activities mean a major visual impact for locals. However, issues of land use and surface and groundwater pollution are also of great importance.

The current state of pollution of the Crişul Alb River is largely due to the situation created by the uncontrolled discharge of impure water from mining and ore processing activities before 1990 (Figure 2). These discharges can be grouped as follows: acid water drainage after the closure of the E.M Barza mine; diffusion of pollutants from the Blojului Valley tailings dump; migration of pollutants from contaminated soils, from areas of mine water flow into the discharge channel; abandoned buildings and piles of rubble, which are washed away by rainwater and the resulting pollution reaches the riverbed and the geology of the area that is prone to create acid drainage. From Figure 2, it can be seen that, once the pumping of groundwater stops, the aquifer recovers and tends to return to its original state, the waters loaded with various pollutants begin to surface, which eventually reach the natural waters near closed mining works.

The problem related to the drainage of acid mine waters is very important in the case of Barza mining, at present it persists even after the mine closes. The amounts and concentrations of such drainage depend on the characteristics of the mine, and are usually characterized by a low $\mathrm{pH}$ and a high content of heavy metals and dissolved salts. These pollutants can cause considerable damage to natural waters and in some cases groundwater.

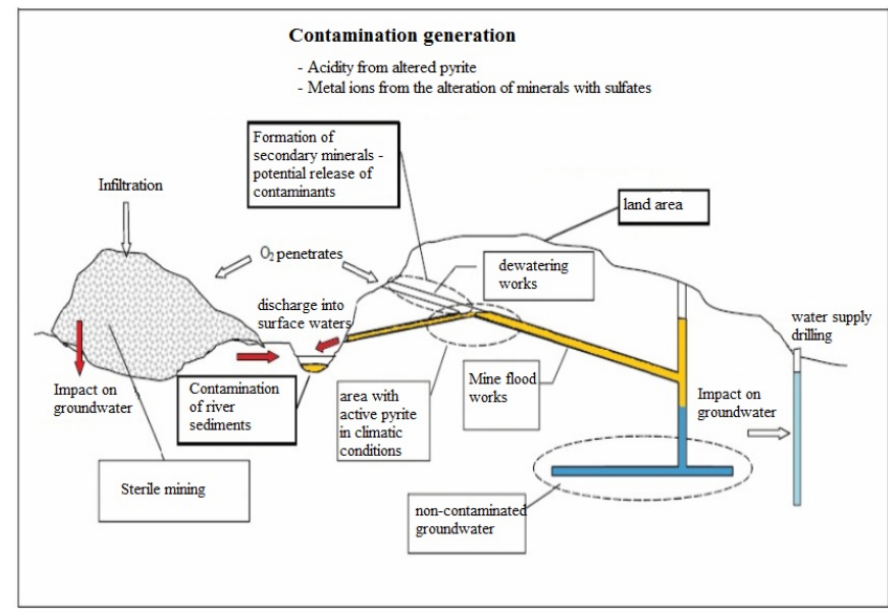

Fig. 2. Sources of contamination generation in the Barza mine area [5]. 
During periods of heavy rainfall, excessive discharges damage natural ecosystems and affect local wildlife and may deprive downstream populations of clean water supplies. In some cases, sediments can block river channels and affect transportation. Pollution does not stop when the mine closes. Discharges from contaminated sites and tailings dumps can take much longer than mine activity.

\section{Methodology}

In order to establish the sources of pollution inside the polluted mining site and the presence of other sources of pollution, a sampling and analysis of water samples of approx. 4 times a year. A minimum of one year is required as a database to generate target values, using samples collected in different seasons and different hydrological regimes. A minimum of four sampling points are required to generate a more relevant target value if more than one sample is used. It will be harvested in the upstream area, at the intersection with other watercourses and at the outflow into the emissary.

Within the Barza perimeter under analysis, 19 soil and surface water samples were collected from the Barza mine site. A total of 15 sterile rock samples of $1.5 \mathrm{~kg}$ each were prepared as composites from five sub-samples. The samples were collected from the surface of the site upstream of the former location of the Barza PVB sol-amount 11 and PVB 12 sol-amount mine, from the PVB21 sol and PVB22 sol site, soil sample taken at the intersection between E.M. Stork and tailings dump Blojului Valley PVB31 soil and PVB32 soil, Soil sample taken from a private household PVB41 soil and PVB42 soil, soil sample taken near decanters PVB51 soil and PVB52 soil, soil sample taken $500 \mathrm{~m}$ from entry into the village of Barza PVB61 soil and PVB62 soil and soil sample taken at the exit from the village Barza PVB71 soil and PVB72 soil. Soil samples were stored in airtight plastic bags to minimize contamination during transport to the laboratory. Water samples were collected from the drains under the mine tailings dump, the 1 Mai gallery and upstream and downstream of the mine site. Along the stream, at distances of $1500 \mathrm{~m}$ downstream from the mine site, four surface water samples (P1VB water -P4VB water) were collected to determine the contribution of mining effluents to environmental pollution. At the sampling site, $\mathrm{pH}$ and electrical conductivity (EC) were measured in situ. Mining effluents and surface water samples were collected in clean polyethylene bottles using a plastic syringe with a membrane. The samples collected were kept in the refrigerator until analyzes were performed (Table 1).

Table 1. The points of sampling of the water and the soil analyzed Barza.

\begin{tabular}{|c|c|c|c|c|c|c|}
\hline $\begin{array}{c}\text { Sampling } \\
\text { points }\end{array}$ & $\begin{array}{l}\text { Geospatial } \\
\text { coordinates }\end{array}$ & $\begin{array}{c}\text { Altitude } \\
(\mathbf{m})\end{array}$ & $\begin{array}{l}\text { Depth } \\
\text { (cm) }\end{array}$ & $\begin{array}{c}\text { Sample } \\
\text { type }\end{array}$ & pH & Observations \\
\hline 1 & 2 & 3 & 4 & 5 & 6 & 7 \\
\hline$P_{1 V B}$ apă & $\begin{array}{l}\text { N } 46^{\circ} 06^{\prime} 09^{\prime \prime} \\
\text { E } 22^{\circ} 51^{\circ} 01^{\prime \prime}\end{array}$ & 458 & & water & 2.8 & $\begin{array}{l}\text { Water samples taken from } \\
\text { the stream upstream of the } \\
\text { EM Barza stream }\end{array}$ \\
\hline $\begin{array}{l}\text { PVB sol- } \\
\text { amontel1 }\end{array}$ & $\begin{array}{l}\text { N } 46^{\circ} 06^{`} 16^{\prime \prime} \\
\text { E } 22^{\circ} 50^{\circ} 53^{\prime \prime}\end{array}$ & 372 & $0-15$ & soil & 6.0 & \multirow{2}{*}{$\begin{array}{l}\text { Soil samples taken from } \\
\text { upstream of the former } \\
\text { mine galleries 1Mai - E.M. } \\
\text { Barza }\end{array}$} \\
\hline $\begin{array}{l}\text { PVB sol- } \\
\text { amonte12 }\end{array}$ & $\begin{array}{l}\text { N } 46^{\circ} 06^{`} 16^{\prime \prime} \\
\text { E } 22^{\circ} 500^{\circ} 53^{\prime \prime}\end{array}$ & 372 & $15-30$ & soil & 6.7 & \\
\hline $\mathrm{P}_{2 \mathrm{VB} \text { apă }}$ & $\begin{array}{l}\text { N } 46^{\circ} 06^{\prime} 22^{\prime \prime} \\
\text { E } 22^{\circ} 500^{\prime} 50^{\prime \prime}\end{array}$ & 265 & & water & 3.2 & $\begin{array}{l}\text { Sample taken from the area } \\
\text { of the former mine gallery } \\
\text { 1Mai - E.M. Barza }\end{array}$ \\
\hline $\mathrm{P}_{\mathrm{VB} 21 \text { sol }}$ & $\begin{array}{l}\text { N } 46^{\circ} 06^{\prime} 22^{\prime \prime} \\
\text { E } 22^{\circ} 50^{\prime} 31^{\prime \prime}\end{array}$ & 365 & $0-15$ & soil & 6.4 & $\begin{array}{l}\text { Soil sample taken from } \\
\text { former E.M. Barza }\end{array}$ \\
\hline
\end{tabular}




\begin{tabular}{|c|c|c|c|c|c|c|}
\hline 1 & 2 & 3 & 4 & 5 & 6 & 7 \\
\hline PvB22 sol & $\begin{array}{l}\text { N } 46^{\circ} 06^{\prime} 22^{\prime \prime} \\
\text { E } 22^{\circ} 50^{\prime} 31^{\prime \prime}\end{array}$ & 365 & $15-30$ & soil & 6.2 & \\
\hline PVB31 sol & $\begin{array}{l}\text { N } 46^{\circ} 06^{\prime} 32^{\prime \prime} \\
\text { E } 22^{\circ} 50^{\circ} 44^{\prime \prime}\end{array}$ & 351 & $0-15$ & soil & 8.0 & \multirow{2}{*}{$\begin{array}{l}\text { Soil sample taken at the } \\
\text { intersection of E.M. Barza } \\
\text { and dump Valley Blojului }\end{array}$} \\
\hline PvB32 sol & $\begin{array}{l}\text { N } 46^{\circ} 06^{\prime} 32^{\prime \prime} \\
\text { E } 22^{\circ} 50^{\circ} 44^{\prime \prime}\end{array}$ & 351 & $15-30$ & soil & 7.3 & \\
\hline PVB41 sol & $\begin{array}{l}\text { N } 46^{\circ} 06^{\prime} 35^{\prime \prime} \\
\text { E } 22^{\circ} 50^{\circ} 40^{\prime \prime}\end{array}$ & 335 & $0-15$ & soil & 7.0 & \multirow{2}{*}{$\begin{array}{l}\text { Soil sample taken from a } \\
\text { private household }\end{array}$} \\
\hline PVB42 sol & $\begin{array}{l}\text { N } 46^{\circ} 06^{\prime} 35^{\prime \prime} \\
\mathrm{E} 22^{\circ} 50^{\circ} 40^{\prime \prime}\end{array}$ & 335 & $15-30$ & soil & 7.3 & \\
\hline PvB51 sol & $\begin{array}{l}\text { N } 46^{\circ} 06^{\prime} 35^{\prime \prime} \\
\text { E } 22^{\circ} 50^{\prime} 38^{\prime \prime}\end{array}$ & 340 & $0-15$ & soil & 2.9 & \multirow{2}{*}{$\begin{array}{l}\text { Soil samples taken near the } \\
\text { decanter }\end{array}$} \\
\hline PVB52 sol & $\begin{array}{l}\text { N } 46^{\circ} 06^{\prime} 35^{\prime \prime} \\
\text { E } 22^{\circ} 50^{\prime} 38^{\prime \prime}\end{array}$ & 340 & $15-30$ & soil & 4.7 & \\
\hline $\mathrm{P}_{3}$ VB apă & $\begin{array}{l}\text { N } 46^{\circ} 06^{\prime} 39^{\prime \prime} \\
\text { E } 22^{\circ} 50^{\circ} 42^{\prime \prime}\end{array}$ & 332 & & water & 3.6 & $\begin{array}{l}\text { Sample of water taken from } \\
\text { the Barza stream near the } \\
\text { settlers }\end{array}$ \\
\hline PvB61 sol & $\begin{array}{l}\text { N } 46^{\circ} 06^{\circ} 44^{\prime \prime} \\
\text { E } 22^{\circ} 50^{\circ} 42^{\prime \prime}\end{array}$ & 336 & $0-15$ & soil & 5.0 & \multirow{2}{*}{$\begin{array}{l}\text { Soil sample taken at } 500 \mathrm{~m} \\
\text { from the entrance to Barza } \\
\text { village }\end{array}$} \\
\hline PVB62 sol & $\begin{array}{l}\text { N } 46^{\circ} 06^{\circ} 44^{\prime \prime} \\
\text { E } 22^{\circ} 50^{\circ} 42^{\prime \prime}\end{array}$ & 336 & $15-30$ & soil & 5.5 & \\
\hline PVB71 sol & $\begin{array}{l}\text { N } 46^{\circ} 07^{\circ} 07^{\prime \prime} \\
\text { E } 22^{\circ} 50^{\circ} 45^{\prime \prime}\end{array}$ & 288 & $0-15$ & soil & 6.3 & \multirow{2}{*}{$\begin{array}{l}\text { Soil sample taken at the exit } \\
\text { from Barza village }\end{array}$} \\
\hline PVB72 sol & $\begin{array}{l}\text { N } 46^{\circ} 07^{\prime} 07^{\prime \prime} \\
\mathrm{E} 22^{\circ} 50^{\circ} 45^{\prime \prime}\end{array}$ & 288 & $15-30$ & soil & 6.7 & \\
\hline $\mathrm{P}_{4 \mathrm{VB} \text { apă }}$ & $\begin{array}{l}\text { N } 46^{\circ} 07^{\circ} 07^{\prime \prime} \\
\text { E } 22^{\circ} 50^{\circ} 45^{\prime \prime}\end{array}$ & 289 & & water & 3.8 & $\begin{array}{l}\text { Sample of water taken at } \\
\text { the discharge in the } \\
\text { emissary of the river Crisul } \\
\text { Alb }\end{array}$ \\
\hline
\end{tabular}

\section{Results}

The water environment component, within the Brad perimeter is affected by the acid mine waters, which spring from the underground through the gallery 1 Mai, closed in 2006, respectively to the precipitation waters that wash the tailings dumps, the ruins of the Barza Mine enclosure and the surrounding rocks. The results of analyzes on the water are presented in Table 2.

Table 2. Average values of water quality indicators in the Barza area in 2020.

\begin{tabular}{|c|c|c|c|c|c|c|}
\hline \multirow[b]{2}{*}{ Indicators } & \multirow[b]{2}{*}{ U.M. } & \multicolumn{3}{|c|}{ Chemical composition } & \multirow[b]{2}{*}{$\begin{array}{c}\text { HG no. } \\
352 / 2005\end{array}$} & \multirow[b]{2}{*}{$\begin{array}{l}\text { Analysis } \\
\text { method }\end{array}$} \\
\hline & & $\begin{array}{c}\text { Barza } \\
\text { stream - } \\
\text { upstream }\end{array}$ & $\begin{array}{l}\text { Mine water- } \\
\text { Gallery } 1 \\
\text { May }\end{array}$ & $\begin{array}{c}\text { Barza } \\
\text { stream- } \\
\text { downstr. }\end{array}$ & & \\
\hline 1 & 2 & 3 & 4 & 5 & 6 & 7 \\
\hline $\mathrm{pH}$ & unit. $\mathrm{pH}$ & 7.600 & 2.300 & 2.550 & $6.5-8.5$ & $\begin{array}{l}\text { SR EN ISO } \\
10523: 2012 \\
\end{array}$ \\
\hline Conductivity & $\mu \mathrm{S} / \mathrm{cm}$ & 625.0 & 3460 & 3235 & $300-500$ & $\begin{array}{l}\text { SR EN } \\
27888: 1997\end{array}$ \\
\hline Sulphates & $\mathrm{mg} / \mathrm{l}$ & 98.2 & 1030 & 1247 & 600 & $\begin{array}{l}\text { STAS 8601- } \\
70\end{array}$ \\
\hline Total ionic iron & $\mathrm{mg} / \mathrm{l}$ & 0.249 & 7.16 & 12.7 & 5 & $\begin{array}{l}\text { SR EN } \\
11885: 2009\end{array}$ \\
\hline
\end{tabular}




\begin{tabular}{|l|c|c|c|c|c|l|}
\hline \multicolumn{1}{|c|}{$\mathbf{1}$} & $\mathbf{2}$ & $\mathbf{3}$ & $\mathbf{4}$ & $\mathbf{5}$ & $\mathbf{6}$ & \multicolumn{1}{|c|}{$\mathbf{7}$} \\
\hline Zinc & $\mathrm{mg} / 1$ & 0.129 & 0.49 & 0.54 & 0.5 & $\begin{array}{l}\text { SR EN } \\
11885: 2009\end{array}$ \\
\hline Copper & $\mathrm{mg} / 1$ & 0.001 & 0.003 & 0.008 & 0.1 & $\begin{array}{l}\text { SR EN } \\
11885: 2009\end{array}$ \\
\hline Lead & $\mathrm{mg} / 1$ & 0 & 0.0065 & 0.0092 & 0.2 & $\begin{array}{l}\text { SR EN } \\
11885: 2009\end{array}$ \\
\hline Total chrome & $\mathrm{mg} / 1$ & 0 & 0.01 & 0 & 1 & $\begin{array}{l}\text { SR EN } \\
11885: 2009\end{array}$ \\
\hline Cobalt & $\mathrm{mg} / 1$ & 0.005 & 0.01 & 0.01 & 1 & $\begin{array}{l}\text { SR EN } \\
11885: 2010\end{array}$ \\
\hline
\end{tabular}

Table 2 presents the results of water analyzes in the 3 sampling points. The determination of the physical-chemical properties of the collected samples was made within ECOIND Bucharest, by the method of atomic absorption spectrometry. From the physicalchemical analysis of the water from the Barza Valley brook in 2020, in the four harvesting campaigns, the annual average values are presented in Table 2, it was found the following:

- an acidic $\mathrm{pH}$ of the water, which indicates a high degree of pollution;

- a high conductivity, which shows a loading with mineral salts of water;

- a high content of sulphates, total ionic iron, zinc, copper.

The sample from the acid mine waters (DMA), representing waters resulting from the drainage from the underground galleries and tailings dumps located along the Barza Valley brook, shows high concentrations of iron $(\mathrm{Fe})$, zinc $(\mathrm{Zn})$ and cadmium $(\mathrm{Cd})$ and a low $\mathrm{pH}$. Due to the high content of dissolved iron and Fe in the suspended particles, the acidic waters of the Barza Valley stream have an ochre-brown colour, the distinct and classic optical sign of mining pollution.

Of the pollution sources identified on the mining site, $80 \%$ of them are from the mining activity and the poor management of the closure of the Barza mining operation, which continues to generate acid mine water. Also, other sources of pollution were identified, in a proportion of approx. $20 \%$, which are of anthropogenic origin, results from the human settlements identified along the Barza Valley stream.

\section{Conclusions}

The component of the environment most affected by pollution, from the Barza mining perimeter, is the surface waters. In order to analyze the quality of these waters, we started from the points of discharge into the emissary of the contaminated waters as a result of the mining activity carried out in this perimeter.

Currently, even if the mining activity has been stopped for about 15 years, the surface waters are strongly affected by polluted waters coming out of underground exploitation, but also by rainfall that washes the surface of the Blojului Valley tailings dump and the mining precinct, the surrounding rocks, which dissolves and entrains metal ions, suspensions etc. in the watercourse.

Regarding the pollutant loads, at a first approximation, most of them increase in the same interval in which the discharge of water into the river increases. For the correct assessment of heavy metal pollutant loads, it would be necessary to take samples during floods, as fine and contaminated river sediments accumulated in low flow conditions are preferably transported when the water discharge increases rapidly.

We thank T. Rusu (Technical University of Cluj Napoca), D. Iancu (National Commission for the Control of Nuclear Activity) and the Faculty of Mines within the University of Petrosani for laboratory assistance. This study was supported by research projects from the University of Petroșani. 


\section{References}

1. M.N. Tijani, S. Onodera and M. A. Adeleye, Mat. and Geoenv. 52 (1), 127-130 (2005)

2. AW. Rose, C.A Cravotta III, Geochemistry of coal mine drainage. In: K.B.C. Brady, M.W. Smith and J. Schueck (Eds.), Coal Mine Drainage Prediction and Prevention in Pennsylvania, Pennsylvania Department of Environmental Protection, Harrisburg. PA, 1:1-22. (1998)

3. J. Römbke, Human and Ecological Risk Assessment 12, 84-101 (2006)

4. E.D. Dunca, Study on the ecological rehabilitation of the areas affected by the mining activity in the Brad mining perimeter (PhD Thesis. University of Petrosani, 2003)

5. M. Sengupta, Environmental Impacts of Mining: Monitoring, Restoration, and Control (CRC Press, 1993) 